\title{
The Influence of Chest Style Learning Methods on the Decreasing of Students Anxiety Level
}

\author{
Sandey Tantra Paramitha*, Badruzaman Badruzaman, \\ Febri Fitria Wulandari \\ Departemen Pendidikan Kesehatan dan Rekreasi \\ Universitas Pendidikan Indonesia \\ Bandung, Indonesia \\ *sandeytantra18@upi.edu \\ Muhtar Asshagab \\ PJKR, FKIP \\ Universitas Halu Oleo \\ Kendari, Indonesia
}

\author{
Made Agus Wijaya \\ PJOK \\ Universitas Pendidikan Ganesha \\ Bali, Indonesia
}

I Wayan Repiyasa

Pendidikan Olahraga, PPs

Universitas Negeri Jakarta

Jakarta, Indonesia

\begin{abstract}
This research aims know the influence of water relay games against a decline in the level of anxiety of students in learning the basic techniques of swimming breast stroke. The research method used is the method of experimentation with the design of the study randomized pretest-posttest control group design. Research instrument used in the form of a questionnaire that was adopted and develop from Hamilton Anxiety Rating Scale (HARS). Participants in the study involving 30 student's sports science, Sports Education and Health Faculty of the Universitas Pendidikan Indonesia force 2017. Determination of the sample in this study using a purposive sampling technique. 30 participants were dividing into two groups, the experimental group and the control group. Data analysis techniques using Paired T-Test and the Independent samples $T$ Test. The results showed that there were significant effects in the form of a decrease in the level of anxiety of students in learning the basic techniques of swimming the breaststroke is at experimental group and the control group with the highest significance $=0000$. Then it can be inferred that the water relay games approach is very effective to reduce the level of anxiety of students in learning the basic techniques of swimming breaststroke.
\end{abstract}

Keywords-adaptation; performance; unanxious

\section{INTRODUCTION}

Swimming is a sport that can be learned by all ages, from babies, children to adults [1]. Naturally humans are able to master swimming skills, because humans have buoyancy [2]. Likewise, the nature of water is able to lift the weight of our body [3], there should be no one who cannot master the swimming movement. Mastery in swimming skills requires good coordination between limb, hand and head movements for the respiration process [4]. Without good coordination the success of achieving swimming learning outcomes will not be optimal. Previous research has been conducted by Badruzaman [5] on students of the Faculty of Sports Education and Health of the Indonesian Education University, Bandung. The results of the study were mostly $30 \%$ of students from the results of the courage test on water. Therefore, at the time of pre-test the courage for water and the basic ability of swimming before the practical course began, most $(80 \%)$ students had not been able to swim. And the results of the courage test on water, there are (30\%) students who have anxiety about water. There are even $(10 \%)$ students who are classified as having high levels of anxiety towards water. So those classified as high levels of anxiety, for example they do not dare to put their heads in the water.

Swimming is the floatation of an object in a liquid due to its importance or lift [6]. It is understandable that swimming is one type of sport that is popular in the community [7] Swimming is a sport that can be taught by everyone from babies, children to adults [8]. Specifically, swimming is a way for people or animals to move their bodies against water [9]. It can be understood that swimming is an activity of humans or animals carried out in water, both in swimming pools, rivers, lakes, and oceans, by trying to lift their bodies to float in order to breathe and move both forward and backward. Breaststroke is the first style most people learn when they start learning to swim [10]. Chest style is often said to be a frog style, this is because there are similarities in the movements of the legs. Breaststroke swimming movement is stretching the back legs [11] the same as the frog's leg movements while swimming, what distinguishes them is the frog legs used to push the water backward using only the soles of the feet while in the breaststroke swimming apart from the soles of the feet as well as the upper legs.

Anxiety is divided into two types [12], the first is trait anxiety is innate anxiety which is a personality factor [13] that is chaotic in giving a reception for a threatening situation or situation. Trait anxiety is a part of a person's personality that is more permanent and feelings of anxiety will arise at each event, for example someone always feels afraid of failure, fear of being judged bad by others and worried about something happening without reason in every situation. The second type 
of anxiety, namely state anxiety is situational anxiety [14], feelings of anxiety only arise in certain situations, fluctuate, change from time to time because it is strongly influenced by the situation and conditions. This type of anxiety is fleeting, only appears in certain situations [15], for example before the match an athlete is nervous, but when the match goes on the anxiety will decrease or disappear, so state anxiety can be triggered by trait anxiety, meaning someone who has trait anxiety tend to experience higher state anxiety. Anxiety can be divided into two types, namely somatic anxiety [16] and cognitive anxiety [17]. Even though trait anxiety and state anxiety have components that are somatic anxiety and cognitive anxiety [18]. So, someone who experiences cognitive anxiety if when he is feeling anxious, he will have negative thoughts, for example fear of being judged bad by the surrounding environment, fear of rejection of the coach, fear and failure. Somatic anxiety is more physically influential [19], for example when you are anxious to feel muscles tighten, blood pressure increases and nausea.

\section{RESEARCH METHOD}

Experimental research is the only method that actually tests hypotheses about cause and effect relationships [20]. The use of experimental methods is intended to know clearly a result that has been tested a treatment within a certain period of time in the sample in the study, so that aspects of research with the subject matter that has been searched can be solved immediately. In accordance with the explanation above, in the outline the design of this research can be described by the writer as follows:

\begin{tabular}{|lllll|}
\hline Treatment Group & $\mathrm{R}$ & $\mathrm{O}$ & $\mathrm{X}$ & $\mathrm{O}$ \\
Control Group & $\mathrm{R}$ & $\mathrm{O}$ & $\mathrm{C}$ & $\mathrm{O}$ \\
\hline
\end{tabular}

Fig. 1. The randomized pretest-posttest control group design [21].

Participants in this study were students of Sports Science at the Faculty of Sports Education and Health of the Indonesian Education University in the 2017 Faculty of Sport Education and Health of the University of Indonesia Education. The participants used were 30 students who were categorized as anxious in swimming sports and could not swim. In this study the instruments used were observation techniques, questionnaires and training methods.

The instrument that will be used in this study is a questionnaire that was adopted and developed from the Hamilton Anxiety Rating Scale (HAM-A). There is a rating scale and Likert scale, the HARS questionnaire consists of 14 items, namely as follows:

TABLE I. 14 QUESTIONS IN THE INSTRUMENT

\begin{tabular}{|l|l|c|c|c|c|c|}
\hline \multirow{2}{*}{ No } & \multicolumn{1}{|c|}{ Question } & \multicolumn{4}{|c|}{ Alternative } \\
\cline { 3 - 6 } & \multicolumn{1}{|c|}{ Answers } \\
\hline 1 & $\begin{array}{l}\text { Anxious feeling } \\
\text { Feeling worried, bad feeling, afraid of your } \\
\text { own mind, sensitive to stimuli or } \\
\text { irritability. }\end{array}$ & & & & & \\
\hline
\end{tabular}

Table 1. Cont.

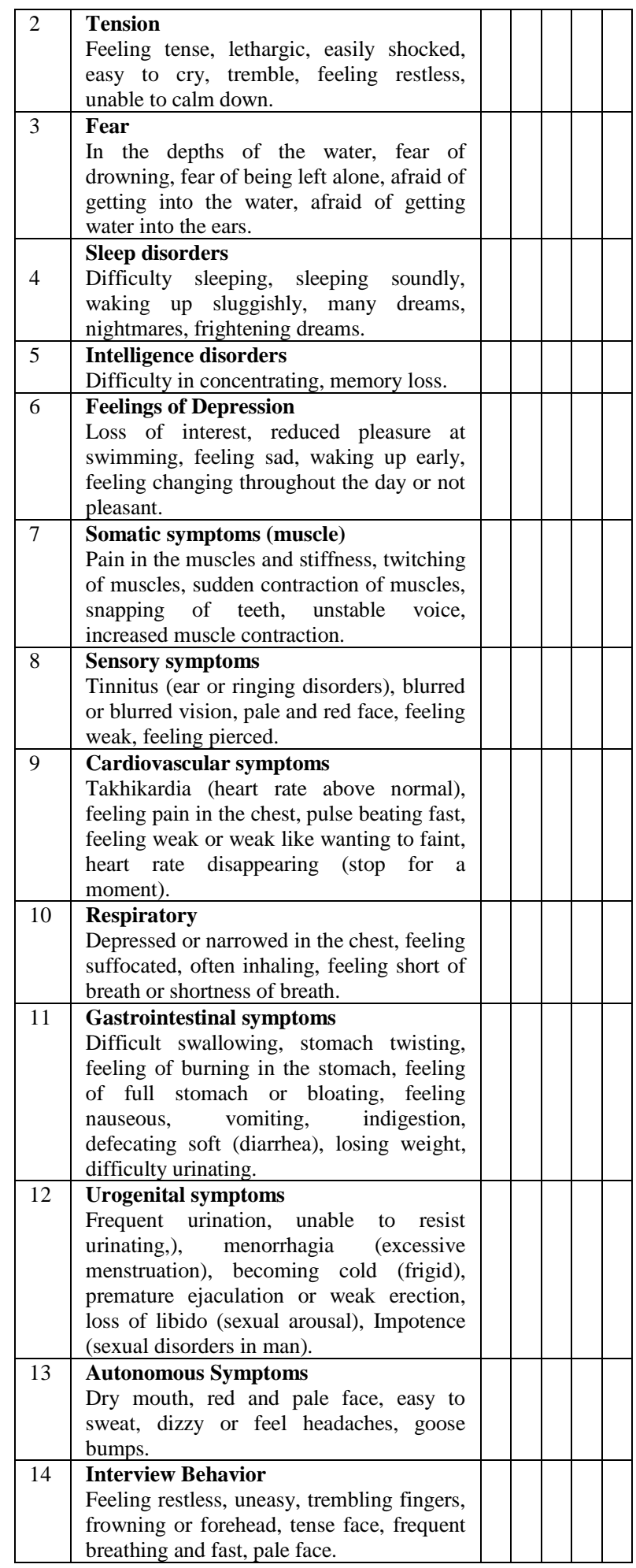

Validity test is carried out to find out whether the instrument is able to measure what is being measured on each instrument, both test and non-test, there are items of question items. In this instrument questionnaire there are 14 questions, the results of the instrument validity: 
TABLE II INSTRUMENT VALIDITY TEST

\begin{tabular}{|l|l|l|l|}
\hline No & \multicolumn{1}{|c|}{ Question } & $\begin{array}{c}\text { Corrected } \\
\text { Item-Total } \\
\text { Correlation }\end{array}$ & Finding \\
\hline 1 & Anxious feeling & 0.706 & $*$ \\
\hline 2 & Tension & 0.535 & $*$ \\
\hline 3 & Fear & 0.706 & $*$ \\
\hline 4 & Sleep disorders & 0.691 & $*$ \\
\hline 5 & Intelligence disorders & 0.535 & $*$ \\
\hline 6 & Feelings of Depression & 0.706 & $*$ \\
\hline 7 & Somatic symptoms (muscle) & 0.691 & $*$ \\
\hline 8 & Sensory Pressure & 0.535 & $*$ \\
\hline 9 & Cardiovascular symptoms & 0.706 & $*$ \\
\hline 10 & $\begin{array}{l}\text { Respiratory / Respiratory } \\
\text { Tubes }\end{array}$ & 0.691 & $*$ \\
\hline 11 & Gastrointestinal symptoms & 0.535 & $*$ \\
\hline 12 & Urogenital symptoms & 0.535 & $*$ \\
\hline 13 & $\begin{array}{l}\text { Autonomous / Vegetative } \\
\text { Symptoms }\end{array}$ & 0.706 & $*$ \\
\hline 14 & Interview Behavior & 0.691 & $*$ \\
\hline
\end{tabular}

Validation test results in the Corrected Item-Total Correlation section of all questions have a positive value and are greater than Rhitung. Then it will be declared valid if it has $r$ count $>r$ table $(0.3061)$ with a significance level of 0.05 in DF $=\mathrm{N}-2$ (total number of samples -2$)=28$. It can be concluded that 14 questions in this questionnaire are declared valid.

\section{RESULTS AND DISCUSSION}

The data obtained from the results of the pretest and posttest questionnaire measuring the anxiety level of the experimental group (which was given treatment method of game-based breaststroke swimming basic techniques) and the control group (which was not given treatment treatment) were still in the form of raw scores, so to find out the results the decline in the level of anxiety in this study needs to be carried out data processing with a system or SPSS program.

\section{A. Experimental Group}

The results of the test decreased the level of anxiety on the results of pretest and posttest in the experimental group by using parametric Paired T-Test. Can be proposed into the research hypothesis as follows:

H0: there was no decrease in the level of anxiety on the results of the experimental group pretest and posttest.

$\mathrm{H} 1$ : there is a decrease in the level of anxiety in the results of the experimental group pretest and posttest.

Decision criteria:

- Significance Value or probability value> 0.05 , then H0 is accepted.

- Significance Value or probability value $<0.05$, then $\mathrm{H} 0$ is rejected.
TABLE III. Instrument VAlidity Test Paired T-Test Test Results EXPERIMENTAL GROUP

\begin{tabular}{|l|c|c|l|}
\hline Experiment Group & T & Df & Sig. (2-tailed) \\
\hline Pretest - Posttest & 10.926 & 14 & $\underline{\boldsymbol{0 . 0 0 0}}$ \\
\hline
\end{tabular}

The results of testing the data obtained a significance value for the two-way test $(2$ tailed $)=0.000$, it is known that the significant value is smaller than 0.05 , it means that $\mathrm{H} 0$ is rejected and $\mathrm{H} 1$ is accepted. Means there is a decrease in the level of anxiety on the results of the experimental group pretest and posttest. The following is a graph of the results of the pretest and posttest questionnaire measuring the anxiety level of the experimental group:

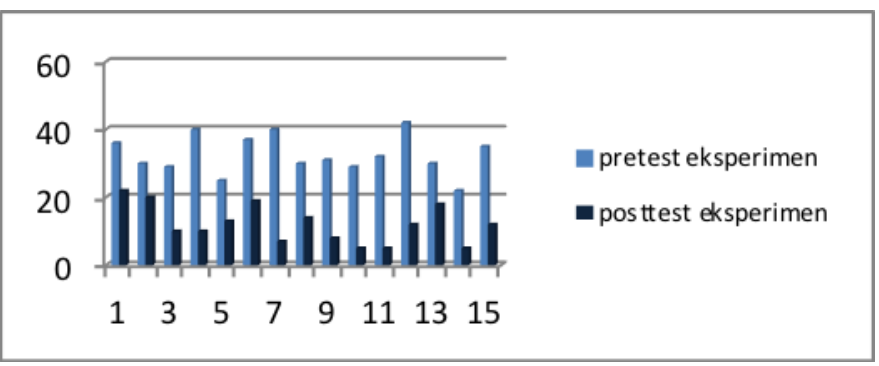

Fig. 2. Pretest chart and posttest experiment group questionnaire

\section{B. Control Group}

The results of the test decreased the level of anxiety in the control group by using parametric Paired T-Test. Can be proposed into the research hypothesis as follows:

H0: there is no decrease in the level of anxiety on the results of the pretest and posttest of the control group.

H1: there is a decrease in the level of anxiety in the results of the pretest and posttest of the control group.

Decision criteria:

- Significance Value or probability value $>0.05$, then H0 is accepted.

- Significance Value or probability value $<0.05$, then $\mathrm{H} 0$ is rejected

TABLE IV. PAIRED T-Test Test Results of The CONTROL GrouP

\begin{tabular}{|l|c|c|l|}
\hline Control Group & T & df & Sig. (2-tailed) \\
\hline Pretest - Posttest & 6.902 & 14 & $\underline{\mathbf{0 . 0 0 0}}$ \\
\hline
\end{tabular}

The results of testing the data obtained a significance value for the two-way test $(2$ tailed $)=0.000$, it is known that the significant value is smaller than 0.05 , it means that $\mathrm{H} 0$ is rejected and $\mathrm{H} 1$ is accepted. Means there is a decrease in the level of anxiety on the results of the pretest and posttest of the control group. The following is a graph of the results of the 
pretest and posttest questionnaire measuring the anxiety level of the control group:

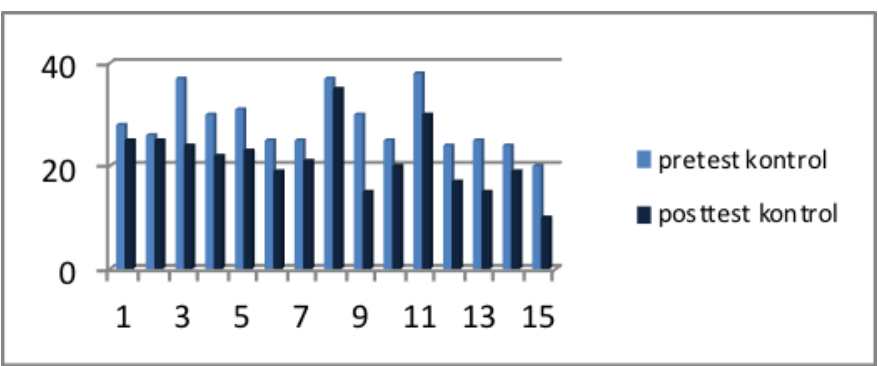

Fig. 3. Graph of pretest results and control group questionnaire posttest

\section{Comparison Results of the Experimental Group and the Control Group}

The results of the comparative test of the results of the values decreased the anxiety level of the experimental group and the control group. Can be proposed into the research hypothesis as follows:

H0: there was no difference between the experimental groups who were given the method of learning the basic techniques of game-based breaststroke swimming and the control group who were not treated treatment for decreasing anxiety levels.

H1: there is a difference between the experimental groups who were given the method of learning the basic techniques of game-based breaststroke swimming and the untreated control group on decreasing anxiety levels.

Decision Criteria:

- Significance Value or probability value $>0.05$, then $\mathrm{H} 0$ is accepted.

- Significance Value or probability value $<0.05$, then $\mathrm{H} 0$ is rejected.

TABLE V. INDEPENDENT SAMPLES TEST RESUlts

\begin{tabular}{|c|c|c|c|c|c|}
\hline & \multicolumn{1}{|c|}{ T } & \multicolumn{1}{|c|}{ Df } & $\begin{array}{c}\text { Sig. (2- } \\
\text { tailed) }\end{array}$ & Finding \\
\hline \multirow{2}{*}{ Grade } & $\begin{array}{c}\text { Equal } \\
\text { variances } \\
\text { assumed }\end{array}$ & 6.337 & 28 & 0.000 & $\mathbf{H}_{\mathbf{0}}$ Rejected \\
\cline { 2 - 6 } & $\begin{array}{c}\text { Equal } \\
\text { variances not } \\
\text { assumed }\end{array}$ & 6.337 & 21.516 & $\underline{\mathbf{0 . 0 0 0}}$ & $\mathbf{H}_{\mathbf{0}}$ Rejected \\
\hline
\end{tabular}

Based on the results in table 5 obtained significant value $=$ 0.000 , meaning that the probability value $<0.05$, it means that $\mathrm{H} 0$ is rejected and $\mathrm{H} 1$ is accepted. This means that there is a difference between the experimental groups who were given the method of learning the basic techniques of game-based breaststroke swimming and the untreated control group on decreasing anxiety levels. Here is a graphical picture of the percentage results in the experimental group and the control group on decreasing anxiety levels:

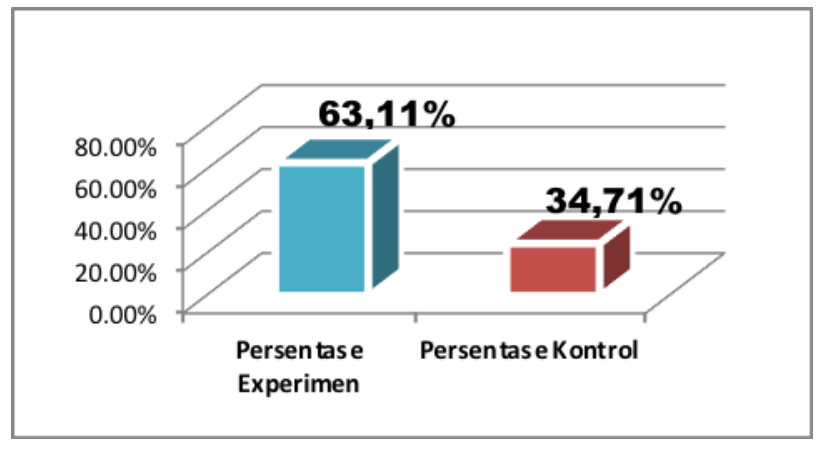

Fig. 4. Increased percentage of experiment and control groups.

\section{CONCLUSIONS}

Based on the results of data analysis processing that has been carried out by the author regarding the effect of gamebased breast technique swimming technique learning methods on reducing anxiety levels in sports students (Sports Science Faculty of Education and Sports Education University of Indonesia force 2017). There was a significant decrease in the level of anxiety in the experimental group pretest and posttest results (given the method of learning breaststroke swimming basic techniques with a game approach). There was a significant decrease in the level of anxiety in the results of the pretest and posttest of the control group (not given treatment). There was an effect of a decrease in the level of anxiety in the experimental group which was given a treatment method of the game-based breaststroke swimming technique and the untreated control group. But it can still be compared from the results of the pretest and posttest on the average of both of them that the more dominant experience of reducing anxiety levels is the experimental group.

\section{REFERENCES}

[1] T.W. Rowland, "Physiological Aspects of Early Specialized Athletic Training in Children". Kinesiology Review, vol. 4(3), pp. 279-291, 2015.

[2] Y. Watanabe, K. Wakayoshi, and T. Nomura, "New evaluation index for the retainability of a swimmer's horizontal posture". PLoS ONE, vol. 12(5), 2017

[3] R. Adelsberger, and G. Tröster, "Experts lift differently: Classification of weight-lifting athletes". In 2013 IEEE International Conference on Body Sensor Networks, BSN 2013, 2013.

[4] W.C. Whiting, R.J. Gregor, G.A. Finerman, J.-W. Noh, B.-S. Park, M. Y. Kim, and G. Rayan, "Kinematic analysis of human upper extremity movements in boxing". Hand, vol. 51(1), pp. 130-6, 2017.

[5] Badruzaman, Ramlan, and Aming, Perbedaan Pengaruh Tingka Kecemasan Pada Air Terhadap Hasil Belajar Keterampilan Renang, 2009.

[6] B.S. Rushall, L.E. Holt, E.J. Sprigings, and J.M. Cappaert, "A reevaluation of forces in swimming". Journal of Swimming Research, vol. 10(Fall), pp. 6-30, 1994

[7] A. Gómez-Bruton, A. Gónzalez-Agüero, A. Gómez-Cabello, J.A Casajús, and G. Vicente-Rodríguez, "Is Bone Tissue Really Affected by Swimming? A Systematic Review". PLoS ONE, 2013.

[8] E. Choi, J.J. Park, K. Jo, and O. Lee, "The influence of a sports mentoring program on children's life skills development". Journal of Physical Education and Sport, vol. 15(2), pp. 264-271, 2015. 
[9] R.I. Holbrook, and T. Burt de Perera, "Three-dimensional spatial cognition: Freely swimming fish accurately learn and remember metric information in a volume". Animal Behaviour, vol. 86(5), pp. 1077-1083, 2013

[10] H. Pashler, M. Mcdaniel, D. Rohrer, and R. Bjork, "Learning styles: Concepts and Evidence". Psychological Science, vol. 9(3), pp. 105-119, 2009.

[11] M. Jaszczak, "The influence of lower limb movement on upper limb movement symmetry while swimming the breaststroke". Biology of Sport, vol. 28(3), pp. 207-211, 2011.

[12] C.D. Spielberger, R.L. Gorsuch, and R.E. Lushene, State-Trait Anxiety Inventory. Mind Garden, 1970.

[13] P.R. Vagg, C.D. Spielberger, and T.P. O'Hearn, "Is the state-trait anxiety inventory multidimensional? Personality and Individual Differences", vol. 1(3), pp. 207-214, 1980.

[14] C.D. Spielberger, "State-Trait Anxiety Inventory (STAI)". Mind Garden, vol. 94061(650), pp. 261-3500, 1983.
[15] D. Suchecki, P.A. Tiba, and R.B. Machado, "REM sleep rebound as an adaptive response to stressful situations". Frontiers in Neurology, APR, 2012

[16] M. Crăciun, "Reducerea anxietății somatice la sportivii de performanță prin antrenament biofeedback. Rezultatele unui studiu pilot. Somatic Anxiety Reduction in Elite Athletes through Biofeedback Training". Results of a Pilot Study, vol. 10(3), pp. 273-276, 2009.

[17] G. Butler, and A. Mathews, Cognitive processes in anxiety. Advances in Behaviour Research and Therapy, 5(1), 51-62, 1983

[18] G. Andrews, "Anxiety, personality and anxiety disorders". International Review of Psychiatry, vol. 3(2), pp. 293-302, 1991.

[19] D. Wolke, "Prevalence and consequences of bullying: What could healthcare services do for intervention?", European Psychiatry, vol. 41, 2017.

[20] D. Segev, "Biostatistics in outcomes research". American Journal of Transplantation, vol. 10, pp. 41-42, 2010.

[21] J.R. Fraenkel, N.E. Wallen, and H.H. Hyun, "BİBLIYYGRAFİSI Bulunacak”. Climate Change 2013 - The Physical Science Basis, vol. 53, 2013. 